\title{
Police Treatment of the Public in Police Stations: Evidence from Zaria, Nigeria
}

\author{
1,a* Ogadimma Arisukwu, ${ }^{1, a}$ Tunde Adebisi, ${ }^{1, b}$ Chisaa Igbolekwu, ${ }^{1, a}$ Festus Asamu \\ ${ }^{a}$ SDG 16, Peace, Justice and Strong Institutions \\ ${ }^{\mathrm{b}}$ SDG 10, Reduced Inequality \\ *First and corresponding author \\ ${ }^{1}$ Department of Sociology, Landmark University
}

\begin{abstract}
The police occupy a very important position in the entire criminal justice system in Nigeria. The nature of police relationship with the people and the manner in which the public were handled at the station and on the street daily within the community affects the way the people perceive them and the level of cooperation they get from the people in curbing crime in the society.
\end{abstract}

The study took place in Zaria, Kaduna state, Northern Nigeria .The study population was the police in Zaria. Three police stations (Zaria City, Sabon Gari and Samaru police stations) were purposively selected reflecting the socio-cultural and demographic backgrounds of Zaria residence and population. The Divisional Police officers and police officers in-charge of crime were interviewed. The police crime and incidence records were examined while the general conduct and social atmosphere of the police and police stations were observed. Using in- depth interview, observational method and police records, it was discovered that the socio economic status of suspects affected how they were treated by the police in the police stations studied. Also the environment a suspect lives affected how they were treated too by the police.

It was recommended that the police make the rule of law their guide in the handling of suspects in the police stations irrespective of socio-demographic variable or area of habitation of the suspects. Police brutality and violations of citizen's rights should be checked by senior police officers while community-policing style should be implemented across communities in Nigeria. 
Keywords; Police Treatment of Suspects, Community Partnership, Rule of Law; Police Station.

\section{Introduction}

Every society needs a form of social control or the other, so as to promote peaceful co-existence and maintenance of order within the society (Cheng. \& Long,2018). Policing therefore started as a communal effort to maintain order and protect properties such as farm lands and animal's miller and Hess (2002).

The police have been assigned the task of crime prevention, crime detection, and the apprehension of criminals Manning, (1978) In Brazil Women police stations are created in municipals to aid victims of intimate partner crimes such as domestic violence and rape ( Perova \& Reynolds, 2017). In carrying out their daily routine services, the police station can be contaminated with illicit drugs (Doran, Deans, Carlo De Filippis,Kostakis, Howitt, 2017). In Nigeria, the police are the most proximate to crime. Apart from that, it has the power, and discretion to determine who get arrested, how he is treated in the station, and sometimes which case is charged to court or settled in the police station.

In carrying out these duties, are there excesses in the way people are handled in the police stations either as suspects or complainant? Also in treating people are there other variables used by the police in clearing and attending to suspects and complainants respectfully? The Nigeria police as a bureaucratic organization are supposed to be guarded by laid down procedure, but sometimes these laws even make it possible for the police to employ their own discretionary power in dealing with certain situations or circumstances. Also, sometimes police may suspend or deliberately neglect the rules in the process of carrying out their law enforcement profession (Arisukwu,(2012).

It is important to note that it is not just enough to make good laws, but how such good laws are enforced by the police have a lot of implications on the attainment of justice in the society. The police therefore have the ability to make or mar its reputation, and public perception, depending on how they conduct themselves while dealing with people in the station and on the street, Arisukwu \& Okunola, (2013) .in fact Manning,(1978) posited that the present form and function 
of any police organization is linked to the history of its development in the light of this, the Nigeria police emerged therefore to protect the commercial interest of the colonial Tamuno (1970)

The police are seen only as agents of the ruling class used to enforce their (ruling class) polices and ideologies at all times in the society. The police therefore the police have the power to criminalize the actions or activities of certain individuals or groups in the society, especially when such actions or activities are perceived as conflict with the interest of the ruling class by the police. in his view ,Eric,(2009), argued that it is the type of training the police receive that influences their attitudes and actions towards the public while carrying out their duties in the community.

The role of the police in preventing crime and ensuring the maintenance of law and order cannot be over emphasized in the society (Cheng. \& Long, 2018). As the leading agents in the law enforcement process, occupy a unique position in the community, Leanne Weber, (2011). Not only the police serve as gateway into the entire criminal justice system, they determine whom to suspect, arrest, detain and sometimes which case actually gets to the court for trial Arisukwu (2017). Study has shown that there exist a relationship between police station's physical environment and public perception of police conduct (Clinton \& Devlin, 2011).

In view of this, the police ought be a means for the people especially underprivileged to obtain justice in the society .It was in light of this that sir Robert Peel, the founder of English police hoped that, the police might reduce crime but would nonetheless avoid the use of repressive legal sanctioning and a military - like presence in society .in fact he hope that, the police might manage public order non- violently and perhaps control the possible discord that might arise between them and the public Manning (1978), Nigeria police community policing training manual (2007), Arisukwu (2012), Arisukwu \& Okunola, (2013).

However, sometimes police seem to turn themselves into the end itself and no longer the means, sometimes people are arrest without the intension of prosecuting them. In some other cases, those who are arrested are either made to suffer more than the punishment their offences would have warranted in the court, or they are manhandled in the presence of questioning. This they were able to do may be because they more likely than other agents of social control to exercise force and authority directly upon citizens. The physical conditions of police stations are stressful and makes detained suspects particularly first timers to demand medical attention (Vincent, Beaufrère, 
Chariot, 2015). Most Nigerian Police station are congested with detained suspects, making the station to be dirty and filled with unpleasant odor. In fact the first welcome you get when you approach police stations in Zaria is a stench oozing out from the congested cell.

Such negative treatment usually causes the public to have wrong impressions of the police in particular and the government in general. So how are people affected by the police display of discretionary power in the stations and on the streets? Are there excesses or rule violations by the police in the process of carry out their duties of law enforcement and maintains of order? What are the social-demographic variables influences the way the police treat people in the police stations either as suspect or complainants.

Do the police deliberate engage in bribe and other corrupt practice or are they spoilt or corrupted by the same public who complain about police corruption in the stations? How fair and equal is the bailing system in the police stations in Zaria? is a bail a right to same individuals and a mere privilege to others with respect to their social- economic status in the society? Are the public even aware when their rights being violated by the police, or do they willingly co-operate with them ? Dose police brutality and unnecessary delays in station affect the reporting of suspects to the police by the public? Finally, to what extent can one say that the Nigeria police are upright, neutral, and protective to all? The search for answers to these questions formed the specific focus of study.

\section{Aim and objectives of the study}

The main aim of this study was to assess the socio-cultural factors responsible for the way people were treated by the police in Zaria Nigeria. The specific objectives include;

To find out the category of suspects and complains that were commonly found in Zaria police stations.

To find out the way such complaints, suspects and complainants were handled in the police stations in Zaria.

To find out what guides the police in taking decisions at work.

To examine the strength of the stations in terms of man power and equipment

\section{Significance of the Study}


This study aims at unveiling some of the short comings if any of the Nigeria police in their day to day operations in stations. It will therefore have both theoretical and practice significance. At the practical level, it will provide information to the government on the need to recognize the important roles the play in the society by improving their working conditions so as to make them (the police) to change and have a better public perception and co-operation in turn.

\section{Theoretical Framework}

This study adopted a combination of Karl Marx's conflict theory and John Dullard's frustration and aggression theory to cover police maltreatment of suspects and the perception of the public towards the police. John Dullard, who is the main proponent of frustration and Aggression theory, used the theory to explain the cause and effect relationship between the suspects, members of the public and the Police. The way the public were maltreated by the police, affects the way the public will in turn relate, trust and support the police in their community.

Marxian scholars assume that, the relationship between the major social groups is one of the exploitation and oppression. So they believe that police are used to oppress and exploit other members of the society by the ruling class. So the police are an instrument of oppression of the ruling class.

The ruling class ideology distorts the true nature of society and serves to legitimize and justify the status quo. In this case the police are there to ensure the exploitation of the ruling class in the society by protecting their interest at all time. This was why the police in colonial and even postcolonial era have been to support the ruling party and their polices. This explains why they are ready to shoot rioters for instance the Tiv riot of 1964, Aba women riot of 1929, Ahmadu Bello University student's riot in 1986 and the fuel pump price increase of 1992.

The economic or substructure determine and influences the super structure. in view of this, it is the way the police are funded by the government that influence the way they respond to reported complainant .sometimes due to lack of adequate funding and personal greed of policemen, money is collected from the suspects or complainant to either aid or abate him/her from the case in the station. However, Marxists failed to realize that other factors such as religion, and ethnicity or race could determine and influence the way the police operate in the Nigerian society. 
This theoretical frame throws more light on the conflicts, differences and preferential treatment people receive from the police in the stations. It equally explains why the less privilege suffers more in the hands of police men in the stations than their privileged counter parts. It is through the application of the conflict theory that one can understand why most police cells are usually filled with youths and members of lower class. So in spite of the severe white collar crimes and corruption committed by the upper class, most of them go uninvestigated and unpunished by the police. How else can you explain the different treatment people receive in the station even when they committed the same offence? Though the frustration and aggression theory explains the negative responds and attitudes the police get from members of the public, it should be noted that both the police and members of the public are important in safe guarding the safety of their community. There should be a synergy between them to effectively prevent and control crime in their community. The primary purpose of government is the welfare and security of lives and property of the people. This fundamental purpose of government cannot be realized by the police alone. The members of the community therefore constitute a social capital that can be harnessed through community-policing and better treatment at police stations by the police authorities.

\section{Methodology}

\section{Study Area}

Zaria is located inside Kaduna state of the Northern part of Nigeria. It is located along KadunaKano route on one hand and kaduna-sokoto route on the other hand. The inhabitants are predominantly farmers .Even those with other occupations still practice subsistence farming. Zaria is made up of other smaller towns with various distinctive features, they include Zaria city which is dominated by Hausa Muslims who are the original settlers with the Emir of Zaria as the Political/Religious leader.

On the other hand, Sabon Gari is dominated by traders and other artisans from all parts of Nigeria who are not Muslims. The distinctive feature here is the high commercial activities that take place here, and the freedom the people living there enjoy, such as drinking and sale of alcohol which ordinarily are not allowed inside the Zaria city. 
Samaru is unique because, it is the place where Ahmadu Bello University (ABU) main campus and the institute of Agricultural research are located. These tertiary institutions constitute pull factors which make it possible for people from various tribes in Nigeria and Africa to migrate in to samara for either work or study in the institutions. These diversities are capable of creating problems of crime and therefore the need for policing.

So apart from few Hausa farmers, Samaru harbors mainly ABU workers and their families. It equally harbors students too. Unlike Zaria city where Islam held sway, both Islam and Christianity abide in samara .Other areas include Government Reserved Area (GRA), and Tudun Wada which has increased social and commercial activities. These areas have various classes of people in the society .So it gives the researcher the opportunity to find out how the people were handled in the station either as suspects or complainants. Zaria was chosen as case study because of its cosmopolitan nature and the variety of people found there.

\section{Sampling}

This study dwelled much on qualitative research methodology. So purposive sampling technique was used to select three police stations which covered different segments of the demographic characteristics of the population of study. Zaria city Divisional police station, Tudun Wada Divisional police station and Samaru Divisional police stations were purposively selected for this study.

\section{Data Collection Technique}

The researcher used non-participant overt observation method to study the three police stations selected for at three weeks. In this case the researcher disclosed his identity to the police, but did not take part in their activities.

Direct observation, in-depth interview, and examination of documents (crime register) were used to collect data in each of the police stations under study. The direct observation enabled the researcher to see things even as they take place in the stations. The crime register was used to collect data on common crimes reported, who the suspects and complainants were and how reports were processed by the police.

\section{Data Analysis Method}


The analysis dwelt much on description, transcription and narration of things observed in the station. For the in-depth interview, simple transcription of respondents responses were done and thematic content analysis were used. In case of documents examined, the researcher described the type of documents examined and things found in them. The units of analysis were the police stations, and their suspects or complainants.

\section{Summary of Findings}

It was discovered that male youths mainly constituted the suspects found in the police stations studied. These youths were accused of criminal offences such as house breaking, theft of household property, robbery, belonging to a gang of suspected criminals, and cheating or defrauding others of money and property. This finding contradicts with the finding in a study in Police stations in Ethiopia which reported that fatalities from road accidents constituted the common reported cases,(Hordofa, Assegid, Girma, Weldemarium 2018). This finding equally excluded the dark figures of crime, which were made up of unreported crimes like rape and domestic violence, (Melo, Boivin \& Morselli, 2020). The true crime records should consist of a combination of reported crime and records of dark crime which can be obtained from hospitals where victims go for treatment, (Melo, Boivin \& Morselli, 2020). It was equally observed that the criminals' complaints were lodged mainly by privileged individuals in the society. The reports of the young and underprivileged members were mainly treated with levity.

During the interrogation process most of the suspects were usually hand cuffed, harassed, and beaten with baton and rifle butt. As a result of these torture and intimidation some of the suspects usually confess their crimes .while a few others stood their ground of innocence. Most of the serious cases were usually charged to court at the end of investigation while the trivial ones were usually settled in the police stations. One of the respondents said;

The police in my area are not friendly at all they are only interested in what they will get from you .Even when you bring complaints to them, without giving out money, nothing happens.

This revealed the way the people were treated by the police. From the quotation above, the less privileged members of the society were the common victims of police maltreatment and brutality. 
The police were mainly guided by the penal code and police act in taking decisions at work. The penal code and police acts cover the Northern and Southern regions of Nigeria respectfully. However, the police equally use their discretionary power to dispose of and settle certain cases which they consider minor. Though the use of discretionary powers helps to decongest the criminal justice systems, it was most often abused by the police. Financial inducement often influences how police handle cases reported regardless of its seriousness. The researcher equally discovered that the police stations did not have adequate equipment and staff strength. The stations were lacking in proper sanitation and detained more suspects than its capacity. A bad stench is what welcomes you into the police counter as a visitor. None of the stations has a patrol vehicle, Walkie-Talkie and a descent residential quarter for the police officers. Similarly; stationery items were not available in the stations. Most often complainants were forced to pay for stationary or fuel before their reports were processed.

\section{Discussion of Findings}

Most of the suspects in police cells were found to be male youths. They were mainly unemployed too. As a result of this denial of employment they were left to struggle for survival on their own. This social disorder makes them to take to crime and behave in a rude and disrespectful manner to the police as argued by frustration and aggression theory. On the other hand, the wealthy, educated and property owing class constituted the major complainants in the police stations. This privilege few reported mainly of stolen goods and other property crimes committed against them to the stations. They enjoy police respect and protection. This is in agreement with Mulcahy, (2015), who argued that in a divided society, the police tend to be closely aligned with the dominant social group and their actions focus on maintaining state security rather than providing routine policing services.

The police therefore like the state is a product and manifestation of irreconcilability of class contradictions (Gough, 2004). It is used to protect the economic interest of the privileged class always. The poor and lower class members of the Nigerian society lack access to financial resources needed to fund companies in manufacturing sector of the economy, (Asaleye, Isoha, Asamu, Inegbedion, Arisukwu \& Popoola, 2018). This explains why there are a lot of property crime complaints in the stations, contract fixing, and other white collar crime which were committed by the educated, and ruling class members in the society were not recorded in the police 
stations studied. It should be noted that the researcher did not find any member of the upper class who was detained for any offence in the stations. This does not mean that they were saints. It is rather because the police as an apparatus of the ruling class were used to protect their interests and actions no matter how criminal and injurious such actions may be in the society .So the rich and privileged class were regarded as being above the law by the police.

The private ownership of property and the inherent class conflicts in a capitalist society like Nigeria create a criminal environment. This is because the actions and activities of the privileged class were rewarded and tolerated by the state (police), while the masses were made targets and scape goats of government laws through the police. The police as a coercive instrument of the state were unequally applied to individuals and groups in the society depending on their socioeconomic positions in the society.

The researcher found that the complaints of the privileged class received swift and urgent attention from the police, because they were able to influence their way through in the station. As a result of injustices in the station the underprivileged classes were unfairly treated by the police simply because they cannot influence the police. Thus the underprivileged constituted the suspects who were detained in the various reported offences. This class of people, who were dominated by the unemployed male youths, were tortured, and detained in the police stations. In fact the police saw the unemployed youths as targets in their investigations of criminal offences.

It was discovered that the police neglected or deliberately abandoned certain portions of the police code and rules which was supposed to guide them in taking decisions at work for selfish and personal gains. For instance bail which ought to be free was often given to suspects that can pay for it. As a result of this, the police sometimes by-pass due process because of what they stand to gain from the case reported, or from the person reporting it.

In the study conducted by Malik (1993), and Bogonjoko, (1973), it was found that members of the public especially the rich influence police decisions in the stations by offering gratification or bribe to them. In a similar study conducted on police treatment of street hawkers in Nairobi, Kenya by Dragsted (2019). The result showed that police collect bribe from hawkers in order to allow them to operate in the streets of Nairobi Kenya. The police equally take bribe to allow informal cross border trade to go on in Benin, West Africa, (Bensassi \& Jarrea, 2019). Conclusion 
The daily practices of the police in the stations are a reflection of the existing social-economic and political inequalities and deprivations in the society. The underprivileged class should realize that the police is created to serve mainly the interest of few elites in the society. So the assertion that the police protects all in the society is wrong because even the law which the police claim to enforce is made by the privileged class to favor and protect their interest in the society. This explains why the less privilege are commonly found in police cells as suspects and accused. They may not be able to afford the price of "justice" and fair treatment by the police.

The police can hardly perform its function effectively and efficiently without reference to wider contexts in which it operates. So, no matter how good the police may seem to be, it cannot isolate itself completely from the people it supposed to protect. Also in as much as police need assistance of members of public in order to achieve remarkable results, it should not allow itself to be corrupted and used by the same public illegally. Police cannot be isolated from the community in which they operate, so through a synergy supported by community policing can the police function better and treat people in a friendly manner.

In conclusion, for there to be a just police that enforces just rules equally in the society, the individuals especially the underprivileged should be given access to the making of law in the society. They should collectively determine which actions or activities are injurious to the society and what form of punishment to give offenders. The police therefore should be publicly created, supervised and directed by members of the community to ensure that it protects all and promotes peace, justice and equality in the society. Democracy and community policing will offer this recognition and empowerment of all in the community to participate and contribute to crime control and prevention. Good governance, economic empowerment and equitable distribution of resources within a society will foster development, peace, social inclusiveness and justice.

\section{Recommendations}

Since the nature and function of the police is a reflection of the socio- economic order in the society, the recommendation of this work is channeled towards the reduction of those crime generating structures in the society. These crime generating structure includes; marginalization and deprivation of the weak and poor. The government should discourage socio-economic and 
political exclusion of minority, youths and women in the scheme of things in the society. Good governance at all levels of leadership (Local, state and Federal) will help create jobs and inspire public trust and confidence on the government. This trust and confidence will reduce the gab of mistrust and lack of confidence on government by the people.

Community policing strategy should be adopted to encourage a better police public synergy in crime prevention in the community, and prevention of human rights abuse of the suspects in police stations. Members of the community, traditional and religious leaders should be mobilized to be part of policing in their various localities and intelligence duly supplied to the police officers about nature of crime and how police officers are performing.

All suspects should be treated equally in accordance with the law irrespective of their demographic variables and status in the society. The people should constitute the eyes and voices of the oppressed and maltreated by the police in police stations. Regular visits by local, traditional, religious and state leaders to police stations to observe the state of the stations and conditions of suspects detained should be undertaken regularly to reduce police abuse of discretionary powers and improve welfare and conditions of police and suspects.

Corruption and other white collar crime and suspects must be adequately apprehended and punished to deter others and promote good governance in the society. Police intelligence gathering should be enhanced with constant training and retraining by the government.

Police stations should be provided with relevant equipment's to operate with by the federal government.

Police remuneration and welfare should be improved to motivate them to serve better by the police service commission and the federal government of Nigeria..

Police stations and cells should be connected with CCTV cameras and erring officers punished accordingly, by the local, state and federal governmet.

\section{References}

Abiola John Asaleye, Lawal Adedoyin Isoha, Festus Asamu, Henry Inegbedion, Ogadimma Arisukwu \& Olabisi Popoola. (2018). Financial Development, Manufacturing Sector and Sustainability: Evidence from Nigeria, The Journal of Social Sciences Research ISSN(e): 
2411-9458, ISSN(p): 2413-6670 Vol. 4, Issue. 12, pp: 539-546, 2018 URL: https://arpgweb.com/journal/journal/7 DOI: https://doi.org/10.32861/jssr.412.539.546

Arisukwu Ogadimma, 2017. An Assessment of Community-Oriented policing training in Benue and Lagos States, Nigeria. Sociology and Criminology Open Access

Arisukwu, O., Igbolekwu, C., Oye, J., Oyeyipo, E., Asamu, F., Rasak, B., \& Oyekola, I. (2020). Community participation in crime prevention and control in rural Nigeria. Heliyon, 6(9), e05015.

Benjamin J. Goold. 2004. CCTV and Policing public Area Surveillance and Police Practices in Britain, Oxford University Press

Bensassi \& Jarrea, 2019). Price discrimination in bribe payments: Evidence from informal crossborder trade in West Africa, World Development

Bob C. Mawby. 2010. Chibnail Revisited: Crime Reporters, the police and 'Law-and-order News' The British Journal of Criminology, vol.50, issue6, pp1060-1070

Bogunjoko ,S. 1978. Evaluating Nigeria police Performance: A case study of Okene. A Degree project submitted to Department of sociology ABU Zaria.

Cheng. C \& Long. W,(2018) .Improving police services: Evidence from the French Quarter Task Force. Journal of Public Economics. Volume 164, August 2018, Pages 1-18

Chukkol, S.K, 1998. Right of Accused Persons under Nigeria Law, Inaugural Lecture Series 12 ABU Zaria.

Clinton \& Devlin (2011). "Is this really a police station?": Police department exteriors and judgments of authority, professionalism, and approachability. Journal of Environmental Psychology, Volume 31, Issue 4, December 2011, Pages 393-406

Doran, Deans, Carlo De Filippis,Kostakis, Howitt, 2017). The presence of licit and illicit drugs in police stations and their implications for workplace drug testing. Forensic Science International, Volume 278, September 2017, Pages 125-136. https://doi.org/10.1016/j.forsciint.2017.06.034

Dragsted. B, (2019). Crackdown economics: Policing of hawkers in Nairobi as violent inclusion. Geoforum,Volume 102, June 2019, Pages https://doi.org/10.1016/j.geoforum.2019.03.016

Eric P. W, 2009. Problem- based learning in police Academies; Adult learning Principles utilized by police Trainers. A dissertation presented to the faculty of the school of education Liberty University.

Gough, 2004). Changing scale as changing class relations: variety and contradiction in the politics of scale. Political Geography

Volume23, Issue 2, February 2004, Pages 185-211. https://doi.org/10.1016/j.polgeo.2003.11.005 
Hordofa, Assegid, Girma, Weldemarium (2018). Prevalence of fatality and associated factors of road traffic accidents among victims reported to Burayu town police stations, between 2010 and 2015, Ethiopia. Journal of Transport \& HealthVolume 10September 2018Pages 186-193

Leanne Weber, 2011. 'It Sounds like they shouldn't be heared: Immigration Checks on the Streets of Sydney

Lee Brown, 1998. Integrating investigative operations through neighborhood oriented policing. The Houston police department.

Maliki A.S, 1993. Justice before trial; Police Pre-trial practices a case study of Kaduna M.Sc. thesis submitted to sociology Department ABU Zaria .

Manning p.K,1978 policing A view from street Good year publishing co .Santa Monica California

Melo. S.N, Boivin. R \& Morselli. C, (2020). Spatial dark figures of rapes: (In)Consistencies across police and hospital data. Journal of Environmental PsychologyVolume 68, April 2020, 101393. https://doi.org/10.1016/j.jenvp.2020.101393

Nigeria police force operation hand book community policing 2007.

Mulcahy.A. (2015). Policing in Divided Societies. International Encyclopedia of the Social \& Behavioral Sciences (Second Edition)2015, Pages 266-272. https://doi.org/10.1016/B9780-08-097086-8.96051-3

Ogadimma Chukwubueze Arisukwu (2012) Policing Trends in Nigeria since Independence (19602012). The Police Journal: June 2012, Vol. 85, issue 2, pp. 151-159.

Ogadimma Chukwubueze, Arisukwu \& Rasheed Akanji Okunola (2013). Challenges Faced by Community-oriented policing Trainees in Nigeria. Developing Country Studies ISSN 2224-607X Vol.3, No.4

Perova e. \& Reynolds S.A. (2017). Women's police stations and intimate partner violence:

Evidence from Brazil. Social Science \& Medicine

Sache, I, 2002. Nigeria police, www.nigeriapolice.org.

Tamuno T.N 1970. The police in modern Nigeria, Ibadan University press Ibadan

Vincent, Beaufrère, Chariot, (2015). Detainees arrested for the first time in French police stations. Journal of Forensic and Legal Medicine, Volume 31April 2015Pages 1-6Volume 174, February 2017, Pages 188-196

Volume 122, October 2019, Pages 462-480. https://doi.org/10.1016/j.worlddev.2019.05.023 